\title{
Detection of Intimin Gene and Its Variants, In E. coli Isolates from Calf Diarrhoea Cases
}

\author{
Vandana Gupta $^{1 *}$, Ashish Roy ${ }^{2}$ and Megha Katare ${ }^{3}$ \\ ${ }^{1}$ Department of Veterinary Microbiology, College of Veterinary Science \& A.H., \\ Rewa, M.P., India \\ ${ }^{2}$ Department of Veterinary Microbiology, College of Veterinary Science \& A.H., \\ Anand, Gujarat, India \\ ${ }^{3}$ Department of Veterinary Pathology, College of Veterinary Science \& A.H., \\ Anjora, Chhatisgarh, India \\ *Corresponding author
}

\section{A B S T R A C T}

The present study was designed to study the presence of intimin gene and its variants in $91 \mathrm{E}$. coli isolates. All $91 \mathrm{E}$. coli isolates were screened for the

Keywords

E. coli, Intimin, Intimin gene variants.

Article Info

Accepted:

21 June 2017

Available Online:

10 August 2017 presence of intimin gene by PCR, among which only 15 isolate (16.8 percent) were positive for eaeA gene. Out of 15 isolates positive for eae (intimin) were assayed for intimin variants viz., eae $\beta 1(811 \mathrm{bp})$, eae $\gamma 1$ (804bp), eae $\gamma 2(808 \mathrm{bp})$, eae $\delta$ (833bp), eae $\zeta$ (206bp), and eae $\xi$ (468bp) by PCR. Eight isolates could be typed using 6 intimin variant primer set and 2 isolate (13.3percent) were positive for eae $\beta 1$ variant, one isolate (6.67percent) was positive for eae $\gamma 1$ and five (33.3percent) were positive for eae $\gamma 2$. Intimin gene codes for different types of protein which are immunogenic in nature and thus it can represent an important tool for E. coli typing in routine diagnostic as well as epidemiological and clonal studies. Different intimin variants are responsible for different host tissue cell tropism which could be taken into consideration to identify the specific intimin variant types responsible for attachment to specific tissue tropism.

\section{Introduction}

Enteropathogenic E. coli (EPEC) is an important category of diarrheagenic E. coli which has been linked to infant diarrhea in the developing world. EPEC harbors a pathogenicity island that encodes a series of proteins involved in the attaching and effacement lesions of the intestinal microvilli of the host cell (Jerse et al., 1990) and the presence of the large EPEC adherence factor (EAF) plasmid, on which also the cluster of genes encoding bundle-forming pili (bfp) is present (Kaper, 1996). Based on these, EPEC strains are classified as typical when they possess the EAF plasmid, whereas atypical EPEC strains do not possess the EAF plasmid (Trabulsi et al., 2002).

Like all diarrheagenic E. coli strains, EHEC and EPEC must first colonize the intestinal mucosa. Both pathovars produce a 
characteristic histopathological feature, known as the "attaching-and-effacing" (A/E) lesion, by subverting the intestinal epithelial cell function (Frankel et al., 1998). This lesion is characterized by the effacement of microvilli and by intimate adherence between the bacteria and the epithelial cell membrane. Marked cytoskeletal changes, including accumulation of polymerized actin, occur directly beneath the adherent bacteria. The formation of $\mathrm{A} / \mathrm{E}$ lesions is governed by a pathogenicity island known as the locus of enterocyte effacement (LEE), which was first described in the EPEC O127 strain E2348/69 (MacDaniel et al., 1995).

The LEE central region contains the eae (for E. coli attachment effacement) gene encoding a 94- to $97-\mathrm{kDa}$ outer membrane protein known as intimin (Jerse et al., 1990). This protein mediates close contact between the bacteria and the target cell, upon interaction with its translocated receptor Tir (for translocated intimin receptor), encoded by a gene located upstream eae (Kenny et al., 1997; Deibel et al., 1998).

Tir had been initially identified as a $90-\mathrm{kDa}$ tyrosine phosphorylated protein from the target cell membrane and was called Hp90 (Rosenshine et al., 1992). In animal models, intimin has been shown to be necessary for EHEC O157:H7 to intensively colonize the intestines and cause diarrhea and $\mathrm{A} / \mathrm{E}$ lesions in calves and colonic edema and $\mathrm{A} / \mathrm{E}$ lesions in piglets (Donnenberg et al., 1993; McKee et al., 1995; Dean-Nystrom et al., 1998). E. coli eae gene have been cloned and sequenced from different EPEC and EHEC strains from different sources.

The overall pattern for these sequences shows high conservation in the $\mathrm{N}$-terminal region and variability in the last C-terminal 280 amino acids of the intimin, where binding to the enterocytes (Frankel et al., 1994) and Tir
(Hartland et al., 1999) occurs. Various studies have investigated the heterogeneity of eae among E. coli strains by amplification of the variable 39 region by $\mathrm{PCR}$ and restriction fragment length polymorphism (RFLP) analysis of PCR products. Schmidt et al., (1993) designed two primer pairs capable of differentiating the eae genes of EPEC and EHEC strains of serogroup O157. Agin and Wolf (1997) provided the existence of atleast 3 immunologically distinct intimin types called $\alpha, \beta$, and $\gamma$. A multiplex PCR was designed to detect eae and simultaneously identify the specific alleles encoding these three intimin variants (Reid et al., 1999). In another study, Adu-Bobie et al., (1998) used antisera to the C-terminal region and PCR to investigate antigenic variation and classify the cell-binding domain of intimin expressed by $\mathrm{A} / \mathrm{E}$ lesion-forming bacterial pathogens. By these means, these authors identified four distinct intimin types: intimin $\alpha$, intimin $\beta$, intimin $\gamma$, and intimin $\delta$. Detection of Intimin alleles/variants represent an important tool for E. coli typing in routine diagnostic as well as epidemiological and clonal studies. The Cterminal end of intimin is responsible for receptor binding, and it has been suggested that different intimins may be responsible for different host tissue cell tropism (Zang et al., 2002).

Intimin type specific PCR assays identified 14 variants of the eae gene that encodes 14 different intimin types and subtypes $(\alpha 1, \alpha 2$, $\beta 1, \beta 2, \gamma 1, \gamma 2 / \theta, \delta / \kappa, \xi, \eta, \imath, \lambda, \mu, \nu$ ), (Blanco et al., 2004) Nevertheless, some EHEC and EPEC strains still express non typeable intimins (China et al., 1998; Pelayo et al., 1999; Reid et al., 1999).

\section{Materials and Methods}

The present study was carried out for PCR based detection of intimin gene variants of $E$. coli isolates obtained from fecal samples of 
diarrhoeic calves. The study was conducted on ninety one field isolates of $E$. coli, which were maintained at the Department of Veterinary Microbiology, Veterinary College, Anand.

\section{DNA extraction}

The genomic DNA of E. coli isolates was isolated according to Wilson (1987) with minor modifications. These DNA samples were used for PCR reactions.

\section{Preparation of broth culture of $E$. coli}

The culture was prepared by inoculating the isolate in Luria broth (HiMedia, Mumbai) and incubating at $37^{\circ} \mathrm{C}$ for $24 \mathrm{~h}$ in a shaker water bath.

\section{Preparation of material for nucleic acid extraction}

About $50 \mathrm{ml}$ of broth culture was centrifuged at $10,000 \mathrm{rpm}$ for $10 \mathrm{~min}$ at $5^{\circ} \mathrm{C}$. The supernatant was discarded and the pellet was used for extraction of nucleic acid extraction.

Following solutions were used for extraction

Tris-EDTA (pH 8.0)

$10 \mathrm{mM}$ Tris- $\mathrm{HCl}$

1 mM EDTA

SDS $(10 \% \mathrm{w} / \mathrm{v})$

Proteinase K solution (20mg/ml, w/v)

5 M Sodium chloride

CTAB (Hexadecyl trimethyl ammonium bromide, $10 \%$ solution in $0.7 \mathrm{M} \mathrm{NaCl}$ )

Saturated phenol (pH 8.0)

Chloroform
Isoamyl alcohol

7.5 M Ammonium acetate

Chilled absolute ethanol

\section{Isolation of genomic DNA by Proteinase-K- SDS method}

Pellet containing bacterial cells was suspended in $2 \mathrm{ml}$ Tris-EDTA (pH-8.0), 250 $\mu \mathrm{l}$ SDS $(10 \% \mathrm{w} / \mathrm{v})$ and $10 \mu \mathrm{l}$ of proteinase $\mathrm{K}$ solution $(20 \mathrm{mg} / \mathrm{ml}, \mathrm{w} / \mathrm{v})$ and incubated for $1 \mathrm{~h}$ at $37^{\circ} \mathrm{C}$.

Subsequently, $500 \mu \mathrm{l}$ of $5 \mathrm{M} \mathrm{NaCl}$ followed by $100 \mu \mathrm{CTAB}(10 \%$ solution in $0.7 \mathrm{M}$ $\mathrm{NaCl}$ ) was added and incubated in water bath for $10 \mathrm{~min}$ at $65^{\circ} \mathrm{C}$.

The solution was spun at $8,000 \mathrm{rpm}$ for 10 min after mixing with equal volume of chloroform: isoamyl alcohol (24:1) and upper phase was transferred to clean microfuge tube.

Equal volume of phenol : chloroform : isoamyl alcohol (25:24:1) was added, mixed well by inverting, spun for $10 \mathrm{~min}$ at 10,000 rpm and upper aqueous phase was transferred again to a clean microfuge tube.

In the collected supernant, the DNA was precipitated with one-tenth volumes of ammonium acetate $(7.5 \mathrm{M})$ and double the volume with chilled absolute ethanol.

Tube was centrifuged for $10 \mathrm{~min}$ at 11,000 rpm and ethanol was discarded.

The pellet was washed in $70 \%$ ethanol and again spun for $5 \mathrm{~min}$ at $11,000 \mathrm{rpm}$.

Ethanol was discarded and pellet was dried.

DNA was resuspended in $200 \mu$ sterile distilled water and kept in water bath at $65^{\circ} \mathrm{C}$ for one hour and stored at $-20^{\circ} \mathrm{C}$ till use. 


\section{Quality checking and quantitation of DNA}

Quality and purity of DNA were checked by agarose gel electrophoresis. 0.8 percent agarose in 0.5X TBE (PH 8.0) buffer (Sambrook et al., 1989) was used for submarine gel electrophoresis. Ethidium bromide $(1 \%)$ was added @ 5 $4 \mathrm{l} / 100 \mathrm{ml}$.

The wells were charged with $5 \mu$ of DNA preparations mixed with $1 \mathrm{X}$ BPB dye.

Electrophoresis was carried out at voltage $5 \mathrm{~V} / \mathrm{cm}$ for $60 \mathrm{~min}$ at room temperature. DNA was visualized under UV transilluminator.

Quantity of DNA was calculated by spectrophotometric method. OD at 260 and 280 were taken in UV spectrophotometer with distilled water as reference.

Concentration $(\mu \mathrm{g} / \mathrm{ml})=\mathrm{OD}$ at $260 \times$ dilution factor $\mathrm{x} 50$

Where 50 is concentration of dsDNA expressed in $1 \mu \mathrm{g} / \mathrm{ml}$ at $\mathrm{OD}$ of 1 .

PCR reaction for Intimin (eae) gene variants

Out of the 91 isolates, fifteen isolates which were positive for intimin gene (eae) were used for detection of intimin variants. Primer details (Table 1)

The following components were used in PCR mixture.

2X PCR Mastermix (Fermentas, Life Sciences):

$4 \mathrm{mM} \mathrm{MgCl}{ }_{2}$

$0.4 \mathrm{mM}$ of each dNTPs (dATP, dCTP, dGTP, dTTP)
0.05 units/ml of Taq DNA polymerase

$150 \mathrm{mM}$ tris-HCl PCR buffer

DNA samples were diluted to a final concentration of $30 \mathrm{ng} / \mu \mathrm{l}$ and $3 \mu \mathrm{l}$ of this preparation was used as template for PCR.

\section{PCR conditions}

PCR was carried out in a final reaction volume of $25 \mu \mathrm{l}$ using $0.2 \mathrm{ml}$ thin wall PCR tube. A master mix for 15 samples was prepared and aliquoted in $22 \mu \mathrm{l}$ quantities in each PCR tube. Three $\mu$ l sample of DNA was added in each tube to make the final volume of $25 \mu \mathrm{l}$ as in Table 2.

PCR tubes containing the mixture were tapped gently and quickly spun at $10,000 \mathrm{rpm}$ for few seconds. The PCR tubes with all the components were transferred to thermal cycler (Eppendorf, Germany).

\section{PCR protocol}

The PCR protocol was as described in Table 3 for the primers used.

\section{Agarose gel electrophoresis}

The following reagents were used for agarose gel electrophoresis

Agarose

$\begin{array}{ll}\text { Agarose } & 2.00 \mathrm{~g} \\ \text { TBE }(0.5 \mathrm{X}) & 100 \mathrm{ml} \\ \text { Ethidium bromide (1\%) } & 5 \mu \mathrm{l}\end{array}$

Tris Borate EDTA (TBE) buffer, pH 8.3 (5X)

Tris HCI

$0.445 \mathrm{M}$

Boric Acid

$0.445 \mathrm{M}$

EDTA 
Ethidium bromide (1\%)

$\begin{array}{ll}\text { Ethidium bromide } & 10 \mathrm{mg} \\ \text { Distilled water } & 1.0 \mathrm{ml}\end{array}$

To confirm the targeted PCR amplification, 5 $\mu l$ of PCR product from each tube was mixed with $1 \mu \mathrm{l}$ of $6 \mathrm{X}$ gel loading buffer from each tube and electrophoresed on 2.0 per cent agarose gel along with 100bp DNA Ladder (GeneRuler- Fermentas) and stained with ethidium bromide (1 per cent solution at the rate of $5 \mu \mathrm{l} / 100 \mathrm{ml}$ ) at constant $80 \mathrm{~V}$ for 30 minutes in $0.5 \mathrm{X}$ TBE buffer. The amplified product was visualized as a single compact band of expected size under UV light and documented by gel documentation system.

\section{Results and Discussion}

Detection of Intimin alleles/variants represent an important tool for $E$. coli typing in routine diagnostic as well as epidemiological and clonal studies. The C-terminal end of intimin is responsible for receptor binding, and it has been suggested that different intimins may be responsible for different host tissue cell tropism (Zang et al., 2002). Intimin type specific PCR assays identified 14 variants of the eae gene that encodes 14 different intimin types and subtypes $(\alpha 1, \alpha 2, \beta 1, \beta 2, \gamma 1, \gamma 2 / \theta$, $\delta / \kappa, \xi, \eta, \imath, \lambda, \mu, v),($ Blanco et al., 2004)

Out of 91 isolates, 15 isolates which were positive for intimin gene were, typed for 6 intimin variant types by PCR amplification using the total 6 sets of primer viz.,

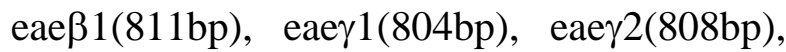
eae $\delta$ (833bp), eae $\zeta$ (206bp), and eae $\xi$ (468bp).

Eight out of 15 isolates could be typed for intimin variant types, however in seven isolates no intimin variant type was detected. Two out of $15(13.3 \%)$ were positive for eae $\beta 1$ ( $811 \mathrm{bp})$ primer. One isolate $(6.67 \%)$ was positive for eae 1 primer (804bp). Five isolates $(33.3 \%)$ were positive for eae 2 (808bp) and no isolate was positive for other three primer viz., eae $\delta$ (833bp), eae $\zeta$ (206bp), and eae $\xi$ (468bp). (Table 4)

Intimin mediates the intimate attachment of the bacteria to the host cell surface and is required for the formation of the characteristic $\mathrm{A} / \mathrm{E}$ lesion associated with EPEC and EHEC infections. Several studies have shown that a considerable heterogeneity exists within the DNA sequences of the eae genes of different E. coli strains and that the corresponding changes in the amino acid sequence also represent antigenic variations. Using immunological and genetic approaches, Agin and Wolf (1997) and Adu- Bobie et al., (1998) revealed the existence of four distinct intimin types: intimin $\alpha$, intimin $\beta$, intimin $\gamma$, intimin $\delta$.

Detection of Intimin alleles/variants represent an important tool for $E$. coli typing in routine diagnostic as well as epidemiological and clonal studies. The C-terminal end of intimin is responsible for receptor binding, and it has been suggested that different intimins may be responsible for different host tissue cell tropism (Zang et al., 2002).

Out of 91 isolates, 15 isolates were typed for 6 intimin variants viz., eae $\beta 1(811 \mathrm{bp})$, eae $\gamma 1$ (804bp), eae 2 (808bp), eae $\delta$ (833bp), eae $\zeta$ (206bp), and eae $\xi$ (468bp) by PCR. Intimin of 8 out of 15 isolates could be typed for intimin variants, while seven isolates could not be typed for any of the variants. Two isolates out of $15(13.3 \%)$ were positive for eae $\beta 1$ primer. One isolate $(6.67 \%)$ was positive for eae 1 primer. Five isolates $(33.3 \%)$ were positive for eae 2 and no isolate was positive for other three primer $v i z$, eae $\delta$ (833bp), eae $\zeta$ (206bp), and eae $\xi$ (468bp). 
Table.1 Details of primers used for PCR for intimin gene variants

\begin{tabular}{|c|c|c|c|c|}
\hline Primers & $\begin{array}{l}\text { Sequences } \\
\left(5,-33^{\prime}\right)\end{array}$ & $\begin{array}{c}\text { Target } \\
\text { Gene }\end{array}$ & \begin{tabular}{|c|} 
Expected \\
Size of \\
amplified \\
product $($ bp $)$
\end{tabular} & Reference \\
\hline $\begin{array}{l}\text { eae- } \beta 1(F) \\
\text { eae- } \beta 1(R)\end{array}$ & $\begin{array}{l}\text { CGC CAC TTA ATG CCA GCG } \\
\text { CTT GAT ACA CCT GAT GAC TGT }\end{array}$ & eae- $\beta 1$ & 811 & $\begin{array}{l}\text { Blanco et } \\
\text { al., (2004) }\end{array}$ \\
\hline $\begin{array}{l}\text { eae- } \gamma 1(F) \\
\text { eae- } \gamma 1(R)\end{array}$ & $\begin{array}{l}\text { AAA ACC GCG GAG ATG ACT TC } \\
\text { AGA ACG CTG CTC ACT AGA TGT C }\end{array}$ & Eae- $\gamma 1$ & 804 & $\begin{array}{l}\text { Blanco et } \\
\text { al., (2004) }\end{array}$ \\
\hline $\begin{array}{l}\text { eae- } \gamma 2(F) \\
\text { eae- } \gamma 2(R)\end{array}$ & $\begin{array}{l}\text { AAA ACC GCG GAG ATG ACT TC } \\
\text { CTG ATA TTT TAT CAG CTT CA }\end{array}$ & eae- $\gamma 2$ & 808 & $\begin{array}{l}\text { Blanco et } \\
\text { al., (2004) }\end{array}$ \\
\hline $\begin{array}{l}\text { eae- } \delta(F) \\
\text { eae- } \delta(R)\end{array}$ & $\begin{array}{l}\text { AAA ACC GCG GAG ATG ACT TC } \\
\text { CTT GAT ACA CCC GAT GGT AAC }\end{array}$ & eae- $\delta$ & 833 & $\begin{array}{l}\text { Blanco et } \\
\text { al., (2004) }\end{array}$ \\
\hline $\begin{array}{l}\text { eae- } \zeta(F) \\
\text { eae- } \zeta(R)\end{array}$ & $\begin{array}{l}\text { GGT AAG CCG TTA TCT GCC } \\
\text { ATA GCA AGT GGG GTG AAG }\end{array}$ & eae- $\zeta$ & 206 & $\begin{array}{l}\text { Blanco et } \\
\text { al., (2004) }\end{array}$ \\
\hline $\begin{array}{l}\text { eae- } \xi(F) \\
\text { eae- } \xi(R)\end{array}$ & $\begin{array}{l}\text { AAA ACC GCG GAG ATG ACT TC } \\
\text { ACC ACC TTT AGC AGT CAA TTT G }\end{array}$ & eae- $\xi$ & 468 & $\begin{array}{l}\text { Blanco et } \\
\text { al., (2004) }\end{array}$ \\
\hline
\end{tabular}

Table.2 Composition for PCR reaction for Intimin gene variants

\begin{tabular}{|c|c|c|}
\hline Components & Quantity & Final Concentration \\
\hline 2X PCR Mastermix & $12.50 \mu \mathrm{l}$ & $1 \mathrm{X}$ \\
\hline DNase free water & $7.50 \mu \mathrm{l}$ & -- \\
\hline Primers Forward & $1 \mu \mathrm{l}$ & $10 \mathrm{pmol} / \mu \mathrm{l}$ \\
\hline Reverse & $1 \mu \mathrm{l}$ & $10 \mathrm{pmol} / \mu \mathrm{l}$ \\
\hline DNA template & $3.0 \mu \mathrm{l}$ & -- \\
\hline Total & $25.0 \mu \mathrm{l}$ & -- \\
\hline
\end{tabular}

Table.3 Steps and conditions of thermocycling for PCR for Intimin gene variants

\begin{tabular}{|c|c|c|c|c|c|c|c|c|c|c|c|c|}
\hline \multirow[t]{2}{*}{$\begin{array}{l}\text { S. } \\
\text { No. }\end{array}$} & \multirow[t]{2}{*}{ Primers } & \multicolumn{2}{|c|}{$\begin{array}{l}\text { Initial } \\
\text { denaturation }\end{array}$} & \multicolumn{2}{|c|}{ Denaturation } & \multicolumn{2}{|c|}{ Annealing } & \multicolumn{2}{|c|}{ Extension } & \multicolumn{2}{|c|}{$\begin{array}{l}\text { Final } \\
\text { extension }\end{array}$} & \multirow[t]{2}{*}{ Cycles } \\
\hline & & Temp & Time & Temp & Time & Temp & Time & Temp & Time & Temp & Time & \\
\hline 1 & eae $\beta 1$ & $94^{\circ} \mathrm{C}$ & $2 \mathrm{~min}$ & $94^{\circ} \mathrm{C}$ & $1 \mathrm{~min}$ & $60^{\circ} \mathrm{C}$ & $1 \mathrm{~min}$ & $72^{\circ} \mathrm{C}$ & $1 \mathrm{~min}$ & $72^{\circ} \mathrm{C}$ & $\begin{array}{c}10 \\
\min \end{array}$ & 35 \\
\hline 2 & eae $\gamma 1$ & $94^{\circ} \mathrm{C}$ & $2 \min$ & $94^{\circ} \mathrm{C}$ & $1 \mathrm{~min}$ & $60^{\circ} \mathrm{C}$ & $1 \mathrm{~min}$ & $72^{\circ} \mathrm{C}$ & $1 \mathrm{~min}$ & $72^{\circ} \mathrm{C}$ & $\begin{array}{c}10 \\
\min \end{array}$ & 35 \\
\hline 3 & eae $\gamma 2$ & $94^{\circ} \mathrm{C}$ & $2 \min$ & $94^{\circ} \mathrm{C}$ & $1 \mathrm{~min}$ & $58^{\circ} \mathrm{C}$ & $1 \mathrm{~min}$ & $72^{\circ} \mathrm{C}$ & $1 \mathrm{~min}$ & $72^{\circ} \mathrm{C}$ & $\begin{array}{c}10 \\
\min \end{array}$ & 35 \\
\hline 4 & eae $\delta$ & $94^{\circ} \mathrm{C}$ & $2 \min$ & $94^{\circ} \mathrm{C}$ & $1 \mathrm{~min}$ & $60^{\circ} \mathrm{C}$ & $1 \mathrm{~min}$ & $72^{\circ} \mathrm{C}$ & $1 \mathrm{~min}$ & $72^{\circ} \mathrm{C}$ & $\begin{array}{c}10 \\
\min \end{array}$ & 35 \\
\hline 5 & eae $\zeta$ & $94^{\circ} \mathrm{C}$ & $2 \min$ & $94^{\circ} \mathrm{C}$ & $1 \mathrm{~min}$ & $62^{\circ} \mathrm{C}$ & $1 \mathrm{~min}$ & $72^{\circ} \mathrm{C}$ & $1 \mathrm{~min}$ & $72^{\circ} \mathrm{C}$ & $\begin{array}{c}10 \\
\min \end{array}$ & 35 \\
\hline 6 & eae $\xi$ & $94^{\circ} \mathrm{C}$ & $2 \min$ & $94^{\circ} \mathrm{C}$ & $\begin{array}{c}1 \\
\min \end{array}$ & $66^{\circ} \mathrm{C}$ & $1 \mathrm{~min}$ & $72^{\circ} \mathrm{C}$ & $1 \mathrm{~min}$ & $72^{\circ} \mathrm{C}$ & $\begin{array}{c}10 \\
\min \end{array}$ & 35 \\
\hline
\end{tabular}


Table.4 Results of Intimin gene and PCR based detection of intimin variant

\begin{tabular}{|c|c|c|c|c|c|c|c|c|}
\hline \multirow[t]{3}{*}{ S. No. } & \multirow{3}{*}{$\begin{array}{l}\text { Isolate } \\
\text { No. }\end{array}$} & \multirow{3}{*}{$\begin{array}{c}\text { Intimin } \\
\text { (eae) } \\
\text { gene } \\
\text { (815bp) }\end{array}$} & \multicolumn{6}{|c|}{ Intimin Variants (eae) } \\
\hline & & & \multicolumn{6}{|c|}{ Gene detected (amplified product size) } \\
\hline & & & $\begin{array}{c}\text { Beta } 1 \\
\beta 1 \\
(811 \mathrm{bp})\end{array}$ & $\begin{array}{c}\text { Gamma1 } \\
\gamma 1 \\
(804 \mathrm{bp})\end{array}$ & $\begin{array}{c}\text { Gamma2 } \\
\gamma 2 \\
(808 \mathrm{bp})\end{array}$ & $\begin{array}{c}\text { Delta } \delta \\
\text { (833bp) }\end{array}$ & $\begin{array}{c}\text { Zeta } \zeta \\
(-206- \\
\text { bp) }\end{array}$ & $\begin{array}{c}\mathrm{Xi} \xi \\
\text { (468bp) }\end{array}$ \\
\hline 1 & AU36 & - & - & - & - & - & - & - \\
\hline 2 & AU37 & - & - & - & - & - & - & - \\
\hline 3 & AU25 & - & - & - & - & - & - & - \\
\hline 4 & AU15 & - & - & - & - & - & - & - \\
\hline 5 & AU16 & - & - & - & - & - & - & - \\
\hline 6 & AU5 & - & - & - & - & - & - & - \\
\hline 7 & AU17 & - & - & - & - & - & - & - \\
\hline 8 & AU18 & - & - & - & - & - & - & - \\
\hline 9 & AU29 & - & - & - & - & - & - & - \\
\hline 10 & AU2 & + & + & - & - & - & - & - \\
\hline 11 & AU24 & + & - & - & - & - & - & - \\
\hline 12 & AU22 & - & - & - & - & - & - & - \\
\hline 13 & AU26 & + & - & - & + & - & - & - \\
\hline 14 & AU27 & - & - & - & - & - & - & - \\
\hline 15 & AU19 & - & - & - & - & - & - & - \\
\hline 16 & AU20 & - & - & - & - & - & - & - \\
\hline 17 & AU6 & + & - & - & - & - & - & - \\
\hline 18 & AU7 & + & - & - & - & - & - & - \\
\hline 19 & AU3 & - & - & - & - & - & - & - \\
\hline 20 & AU4 & - & - & - & - & - & - & - \\
\hline 21 & AU23 & - & - & - & - & - & - & - \\
\hline 22 & AU12 & - & - & - & - & - & - & - \\
\hline 23 & AU38 & - & - & - & - & - & - & - \\
\hline 24 & AU39 & - & - & - & - & - & - & - \\
\hline 25 & AU21 & - & - & - & - & - & - & - \\
\hline 26 & AU1 & - & - & - & - & - & - & - \\
\hline 27 & AU8 & - & - & - & - & - & - & - \\
\hline 28 & AU9 & - & - & - & - & - & - & - \\
\hline 29 & AU40 & - & - & - & - & - & - & - \\
\hline 30 & AU28 & - & - & - & - & - & - & - \\
\hline 31 & AU32 & + & - & - & - & - & - & - \\
\hline 32 & AU33 & + & - & - & + & - & - & - \\
\hline 33 & AU13 & + & + & + & - & - & - & - \\
\hline 34 & AU14 & - & - & - & - & - & - & - \\
\hline 35 & AU30 & - & - & - & - & - & - & - \\
\hline 36 & AU31 & - & - & - & - & - & - & - \\
\hline 37 & $\mathrm{VC} 4$ & - & - & - & - & - & - & - \\
\hline 38 & VC3 & - & - & - & - & - & - & - \\
\hline 39 & OF17 & - & - & - & - & - & - & - \\
\hline 40 & OF11 & - & - & - & - & - & - & - \\
\hline 41 & OF10 & - & - & - & - & - & - & - \\
\hline 42 & OF16 & - & - & - & - & - & - & - \\
\hline 43 & OF12 & - & - & - & - & - & - & - \\
\hline
\end{tabular}




\begin{tabular}{|c|c|c|c|c|c|c|c|c|}
\hline 44 & OF4 & - & - & - & - & - & - & - \\
\hline 45 & OF19 & - & - & - & - & - & - & - \\
\hline 46 & OF21 & - & - & - & - & - & - & - \\
\hline 47 & OF14 & - & - & - & - & - & - & - \\
\hline 48 & OF15 & - & - & - & - & - & - & - \\
\hline 49 & OF24 & + & - & - & - & - & - & - \\
\hline 50 & OF25 & + & - & - & - & - & - & - \\
\hline 51 & OF26 & - & - & - & - & - & - & - \\
\hline 52 & OF7 & - & - & - & - & - & - & - \\
\hline 53 & OF1 & - & - & - & - & - & - & - \\
\hline 54 & OF27 & - & - & - & - & - & - & - \\
\hline 55 & OF22 & - & - & - & - & - & - & - \\
\hline 56 & OF23 & - & - & - & - & - & - & - \\
\hline 57 & OF18 & - & - & - & - & - & - & - \\
\hline 58 & OF13 & - & - & - & - & - & - & - \\
\hline 59 & OF552 & - & - & - & - & - & - & - \\
\hline 60 & VC5 & - & - & - & - & - & - & - \\
\hline 61 & VC6 & - & - & - & - & - & - & - \\
\hline 62 & OF8 & - & - & - & - & - & - & - \\
\hline 63 & OF9 & - & - & - & - & - & - & - \\
\hline 64 & JU17 & + & - & - & + & - & - & - \\
\hline 65 & JU18 & + & - & - & + & - & - & - \\
\hline 66 & JU9 & - & - & - & - & - & - & - \\
\hline 67 & JU3 & - & - & - & - & - & - & - \\
\hline 68 & JU4 & + & - & - & + & - & - & - \\
\hline 69 & JU5 & - & - & - & - & - & - & - \\
\hline 70 & JU11 & - & - & - & - & - & - & - \\
\hline 71 & JU12 & - & - & - & - & - & - & - \\
\hline 72 & JU13 & + & - & - & - & - & - & - \\
\hline 73 & JU16 & - & - & - & - & - & - & - \\
\hline 74 & JU10 & + & - & - & - & - & - & - \\
\hline 75 & JU8 & - & - & - & - & - & - & - \\
\hline 76 & JU14 & - & - & - & - & - & - & - \\
\hline 77 & JU1 & - & - & - & - & - & - & - \\
\hline 78 & JU6 & - & - & - & - & - & - & - \\
\hline 79 & JU7 & - & - & - & - & - & - & - \\
\hline 80 & JU2 & - & - & - & - & - & - & - \\
\hline 81 & JU15 & - & - & - & - & - & - & - \\
\hline 82 & VC1 & - & - & - & - & - & - & - \\
\hline 83 & $\mathrm{VC} 2$ & - & - & - & - & - & - & - \\
\hline 84 & AU10 & - & - & - & - & - & - & - \\
\hline 85 & AU11 & - & - & - & - & - & - & - \\
\hline 86 & AU34 & - & - & - & - & - & - & - \\
\hline 87 & AU35 & - & - & - & - & - & - & - \\
\hline 88 & OF6 & - & - & - & - & - & - & - \\
\hline 89 & OF2 & - & - & - & - & - & - & - \\
\hline 90 & OF3 & - & - & - & - & - & - & - \\
\hline 91 & OF20 & - & - & - & - & - & - & - \\
\hline
\end{tabular}

+: amplification of desired product size, -: no amplification 
Our findings were in accordance with that of finding of Reid et al., (1999) who detected the eae gene and simultaneously identified specific alleles in 87 pathogenic E. coli strains encoding for $\alpha, \beta$ and $\gamma$ intimin variants. Blanco et al., (2004) who also identified eae $\beta 1$ variant in 41 isolates, eae $\gamma 1$ in 82 isolates, three isolates had eae 2 , one isolate showed eae $\delta, 13$ isolates had eae $\varepsilon$, and 8 isolates had eae $\zeta$ among 514 samples of $E$. coli from diarrheic calf. Oswald et al., (2000) also studied the distribution of different types of intimin variants, among the EPEC and EHEC and identified new intimin variant " $\varepsilon$ " which is very much similar to intimin $\beta$.

Blanco et al., (2005) studied intimin variants among 51 eae positive $E$. coli strains and found that EPEC strain harbored variety of intimin variants with eae- $\beta 1$ being most frequent and also identified new intimin variant gene (eae- $\eta 2)$.

There is paucity of literature regarding the intimin gene variants.

Different intimin types and subtypes are closely associated with different pathogenic E. coli clones could contribute to our understanding of the evolution of intimin genes. Since intimin is found to be a $94-97 \mathrm{kda}$ protein and is immunogenic in nature it can targeted for vaccine designing against pathogenic E. coli strains.

Intimin gene codes for different types of protein which are immunogenic in nature and thus it can represent an important tool for $E$. coli typing in routine diagnostic as well as epidemiological and clonal studies. Different intimin variants are responsible for different host tissue cell tropism which could be taken into consideration and further work could be done to identify the specific intimin variant types responsible for attachment to specific tissue tropism. Intimin interaction with the host cell unfolds a novel mechanism of pathogen host cell interaction in the form of bacterial secreted protein translocated on host cell membrane acting as a receptor for bacterial protein and this pathogenic mechanism needs to be studied further for understanding tissue tropism of pathogen. Intimin protein being immunogenic in nature can be target for vaccine design for production of vaccine against pathogenic $E$. coli strains.

\section{Acknowledgement}

The authors are thankful to Dean, Anand Veterinary College and Professor, Animal Biotechnology Laboratory, AAU, Anand for rendering Lab. facility to carry out the work.

\section{References}

Adu-Bobie, J., Frankel, G., Bain, C., Goncalves, A.G., Trabulsi, L.R., Douce, G., Knutton, S. and Dougan, G. (1998). Detection of Intimins $\alpha, \beta, \gamma$ and $\delta$, Four Intimin Derivatives Expressed by Attaching and Effacing Microbial Pathogens. J. Clin. Microbiol. 36: 662668.

Agin, T. S., and Wolf, M. K. (1997). Identification of a family of intimins common to Escherichia coli causing attaching-effacing lesions in rabbits, humans, and swine. Infect. Immun. 65:320-326.

Blanco, M., Blanco, J.E., Mora, A., Dahbi, G., Alonso, M.P., Gonzalez, E.A., Bernardez, M. and Blanco, J. (2004). Serotypes, Virulence genes and Intimin Types of Shiga toxin (verotoxin)producing Escherichia coli Isolates from cattle in Spain and Identification of a New Intimin variant gene (eae- $\xi$ ). J. Clin. Microbiol. 42: 645-651.

Blanco, M., Schumacher, S., Tasara, T., Zweifel, C., Blanco, J. E., Dahbi, G., 
Blanco, J. and Stephan, R. (2005). Serotypes, intimin variants and other virulence factors of eae positive Escherichia coli strains isolated from healthy cattle in Switzerland. Identification of new intimin variant gene (eae- $\eta 2$ ). BMC Microbiol. 5:23.

China, B., Pirson, V. and Mainil. J. (1998). Prevalence and molecular typing of attaching and effacing Escherichia coli among calf populations in Belgium. Vet. Microbiol. 63:249-259.

Dean-Nystrom, E. A., Bosworth, B. T., Moon, H. W. and O'Brien, A. D. (1998). Escherichia coli O157:H7 requires intimin for enteropathogenicity in calves. Infect. Immun. 66:4560-4563.

Deibel, C., Kramer, S., Chakraborty, T. and Ebel, F. (1998). EspE, a novel secreted protein of attaching and effacing bacteria, is directly translocated into infected host cells, where it appears as a tyrosine-phosphorylated $90 \mathrm{kDa}$ protein. Mol. Microbiol. 28:463-474.

Donnenberg, M. S., Tzipori, S., McKee, M. L., O'Brien, A. D., Alroy, J. and Kaper. J. B. (1993). The role of the eae gene of enterohemorrhagic Escherichia coli in intimate attachment in vitro and in a porcine model. J. Clin. Investig. 92:1418-1424.

Frankel, G., Phillips A. D., Rosenshine, I., Dougan, G., Kaper, J. B and Knutton, S. (1998). Enteropathogenic and enterohaemorrhagic Escherichia coli: more subversive elements. Mol. Microbiol. 30:911-921.

Hartland, E. L., Batchelor, M., Delahay, R.M., Hale, C., Matthews, S., Dougan G., Knutton, S., Connerton, I. and Frankel, G. (1999). Binding of intimin from enteropathogenic Escherichia coli to Tir and to host cells. Mol. Microbiol. 32:151-158.

Jerse, A. E., Yu, J., Tall, B. D. and Kaper, J. B. (1990). A genetic locus of enteropathogenic Escherichia coli necessary for the production of attaching and effacing lesions on tissue culture cells. Proc. Natl. Acad. Sci. USA 87: 7839-7843.

Kaper, J.B. (1996). Defining EPEC. Rev. Microbiology. 27: 130-133.

Kenny, B., DeVinney, R., Stein, M., Reinscheid, D. J., Frey, E. A. and Finlay, B. B. (1997). Enteropathogenic E. coli (EPEC) transfers its receptor for intimate adherence into mammalian cells. Cell 91:511-520.

MacDaniel, T. K., Jarvis, K. G., Donnenberg, M. S. and Kaper, J. B. (1995). A genetic locus of enterocyte effacement conserved among diverse enterobacterial pathogens. Proc. Natl. Acad. Sci. USA 92:1664-1668.

McKee, M. L., Melton-Celsa, A. R., Moxley, R. A., Francis, D. H. and O'Brien, A. D. (1995). Enterohemorrhagic Escherichia coli $\mathrm{O} 157: \mathrm{H} 7$ requires intimin to colonize the gnotobiotic pig intestine and to adhere to HEp-2 cells.Infect. Immun. 63:3739-3744.

Oswald,E., Schmidt, H., Morabito, S., Karch,H., Marches, O., and Caprioli, A.(2000). Typing of Intimin Genes in Human and Animal Enterohemorrhagic and Enteropathogenic Escherichia coli: Characterization of a New Intimin Variant J. Clin. Microbiol.68:64-71.

Pelayo, J. S., Scaletsky, I. C., Pedroso, M. Z., Sperandio, V., Giron, J. A., Frankel, G.and Trabulsi, L. R. (1999). Virulence properties of atypical EPEC strains. J. Med. Microbiol. 48:41-49.

Reid, S. D., Betting, D. J. and Whittam, T. S. (1999). Molecular detection and identification of intimin alleles in pathogenic Escherichia coli by multiplex PCR. J. Clin. Microbiol. 37:2719-2722.

Rosenshine, I., Donnenberg, M. S., Kaper, J. B. and Finlay. B. B. (1992). Signal 
transduction between enteropathogenic Escherichia coli (EPEC) and epithelial cells: EPEC induces tyrosine phosphorylation of host cell proteins to initiate cytoskeletal rearrangement and bacterial uptake. EMBO J. 11:35513560.

Sambrook, K.J., Fritsch, E.F., Manlatis, T. (1989). Molecular Cloning: a laboratory manual. Cold Spring Harbor Laboratory, Cold Spring Harbor, NY. Pp 125-128.

Schmidt, H., Russmann, H. and Karch, H. (1993). Virulence determinants in nontoxinogenic Escherichia coli $\mathrm{O} 157$ strains that cause infantile diarrhea. Infect. Immun. 61:4894-4898.

Trabulsi, L.R., Keller, R. And Tardelli
Gomes, T.A. (2002). Typical and atypical enteropathogenic Escherichia coli. Emerg. Infect. Dis. 8: 508-513.

Wilson, K. (1987). Preparation of genomic DNA from bacteria. In: Current protocols in molecular biology. Vol. 1 (Ausbedal, F.M., Brent, R.E., Kirston, D.D., Moore, J.G.; Seidman, J.A., Smith and Struhl, K. Eds). John wiley and Sons. New York. 2.4.1

Zang, W.L., Kohler,B., Oswald, E., Beutin, L., Karch, H., Morabito, S., Caprioli, A., Suerbaum, S. and Schmidt, $\mathrm{H}$. (2002). Genetic diversity of intimin gene ogb attaching and Effacing Escherichia coli Strains. J. of. Clinical. Microbiol. 40: 4486-4492.

\section{How to cite this article:}

Vandana Gupta, Ashish Roy and Megha Katare. 2017. Detection of Intimin Gene and Its Variants, In E. coli Isolates from Calf Diarrhoea Cases. Int.J.Curr.Microbiol.App.Sci. 6(8): 2625-2635. doi: https://doi.org/10.20546/ijcmas.2017.608.312 